\title{
強制対流下における結霜時の熱伝達 一六フッ化硫黄・空気系および二酸化炭素・空気系の場合—
}

\author{
河 村 文 雄・沜 田 時 男 \\ 山 川 紀 夫・大 谷 茂 盛 \\ 東北大学工学部 化学工学科*
}

\begin{abstract}
六フッ化硫黄 $\left(\mathrm{SF}_{6}\right)$ ・空気系および二酸化炭素 $\left(\mathrm{CO}_{2}\right)$ ・空気系混合ガスを冷却した平板上に流し, $\mathrm{SF}_{6}$ 抢よび $\mathrm{CO}_{2}$ が析出する際の析出層・気流間に打ける局所熱伝達係数 ‘ $h$ ’を実験的に検討した.

実験結果によるとかかる系に扩兴結霜時の 局所熱伝達係数は本実験の範囲内では混合ガス系の 違いによる影響をそれほど受けないことがわかった。ししい結霜時の局所熱伝達俰数は単純伝熱の 場合の Sieder-Tate の式拉よび Hausen の式と比較し 1.5 2 倍程度大きな值を示した。この要因 として定性的には熱移動に及ぼす物質移動の影響, 層表面の凹凸による伝熱面積の増加，および凹 凸による境界層の乱れなどが考吕れる。
\end{abstract}

\section{緒言}

分離操作には種々の場合があるが，気体混合物の分離 法の特殊な場合の一つとして凝固点の違いを利用して混 合ガス中のある成分を霜状析出物として取り出し, 分離 ・精製を行ら方法がある.この結霜現象を利用した分離 法の最近の例としてはウランの遠心分離法による濃縮過 程でのコールドトラップなどがある. しかしこのような 結霜現象は相変化を伴う熱と物質の同時移動現象であ り, しかも混合ガスの種類や条件によって析出物が昇華 によってあるいは凝縮・凝固によって生成する場合があ るなど，その実験および解析にあたっては多くの困難を 伴うのが常である.

結霜過程を扱った従来の研究の大部分は自然対流およ び強制対流下の両方とも混合ガス系として水蒸気・空気 系を取り扱ったいわゆる霜の場合で, 著者らも強制対流 下の水平平板上 ${ }^{8)}$, 垂直円筒まわり ${ }^{11)}$ ，および自然対流 下の矩形密閉系 ${ }^{10}$ 亿㧍ける結霜過程についてすで報告 を行っている. しかしながら水蒸気・空気系以外の系の 結霜現象を扱った研究はきわめて少なく, 二酸化炭素・ 窒素系に括いて強制対流下で実験を行ったものなど,8) 2〜3 を数えるにすぎず，このような混合ガス系の場合 に抢ける結霜時の熱掞よび物質移動機構に関してはいま だ充分な解明がなされているとはいいがたい。

本報では結霜を伴う場合の混合ガスの分離過程におけ る熱伝達機構を解明する目的で, 六フッ化硫黄 $\left(\mathrm{SF}_{6}\right)$ ・ 空気あるいは二酸化炭素 $\left(\mathrm{CO}_{2}\right)$ ・空気の混合ガスを冷却 した水平平板上に流し, その面上に $\mathrm{SF}_{6}$ あるいは $\mathrm{CO}_{2}$ を析出させ, その際の析出層の状態, 密度および析出層

* $\overline{\bar{T} 980}$ 仙台市荒巻字青葉
・気流間の局所熱伝達係数などを実験的に求め検討を行 い, さらに前報》の水蒸気・空気系のいわゆる霜の場合 の結果とも比較検討を行った.

\section{1. 実験装置および測定方法}

\section{$1 \cdot 1$ 実験装置}

実験装置の概略を Fig. 1 に示した。本実験では同伴 ガスとして空気を使用したが， $\mathrm{SF}_{6}$ または $\mathrm{CO}_{2}$ の析出 層を析出させる際同時に水の霜が析出し $\mathrm{SF}_{6}$ や $\mathrm{CO}_{2}$ の 析出層に影響を及洔すことがないよう, 混合ガス中の水 分を充分除去する必要があるので脱湿装置に充分留意し た. そこで送風機(1)からの空気は気泡塔(2)で冷水々接触 させ, 熱交換器(4)で冷却し, さらにシリカゲル充填塔(8) を通し脱湿を充分行った。このようにして得られた乾燥 空気をオリフィス(9)で計量後, ヒーター(10)で加熱し所定 温度とし混合器(4)へ導く. 一方, $\mathrm{SF}_{8}$ ガスもしくは $\mathrm{CO}_{2}$ ガスはボンベ(11より供給し, シリカゲル乾燥器12を通し 水分を除去し, オリフィス(13)で計量後, 混合器(14で乾燥 空気と所定濃度に混合し測定部15人導いた，伝熱板は液 体空素团を用い $-150^{\circ} \mathrm{C}$ まで泠却した。

測定部の詳細を Fig. 2 亿示した。気流流路は高さ 22 $\mathrm{mm}$, 幅 $140 \mathrm{~mm}$ の矩形断面で, 入口および出口には多 孔板(6)をも5け気流の整流を行った。ダクト上部は析出 層の観察ができるようにアクリル樹脂板を用いた。伝熱 板には厚さ, $30 \mathrm{~mm}$, 幅 $140 \mathrm{~mm}$, 長さ $1,400 \mathrm{~mm}$ の ステンンススチール板を用い，その側壁には伝熱板内の 温度分布を求めるため図中の・印で示した 12 個所に 0.8 $\mathrm{mm} \phi$ の孔を深さ $45 \mathrm{~mm}$ まであけ, その中に $200 \mu \phi$ の 銅・コンスタンタン熱電対を挿入した。な拈装置の測定 部のほ核全体を吸湿性のきわめて少ない保温材でおおい 


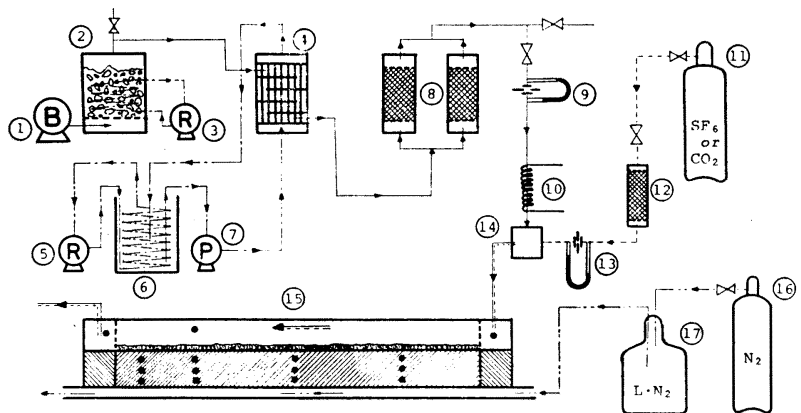

(1) Blower

(6) Cold methanol (11) $\mathrm{SF}_{6}$ or $\mathrm{CO}_{2}$

(2) Bubbling tower (7) Pump

(12) gas bomb

(8) Packed column (13) of silicagel

(9) Of Silicicage

(5) Refrigerator (10) Heater (15) Test section - - $\mathrm{N}_{2}$ or liquid $\mathrm{N}_{2}$

(14) Mixing chamber

(5) Refrigerator (10) Heater (15) Test section - - $\mathrm{N}_{2}$ or liquid $\mathrm{N}_{2}$

(16) $\mathrm{N}_{2}$ gas bomb

(17) Liquid $\mathrm{N}_{2}$

$-\mathrm{Air}_{6}$ or $\mathrm{CO}_{2}$ gas

R-22 or
cold methanol

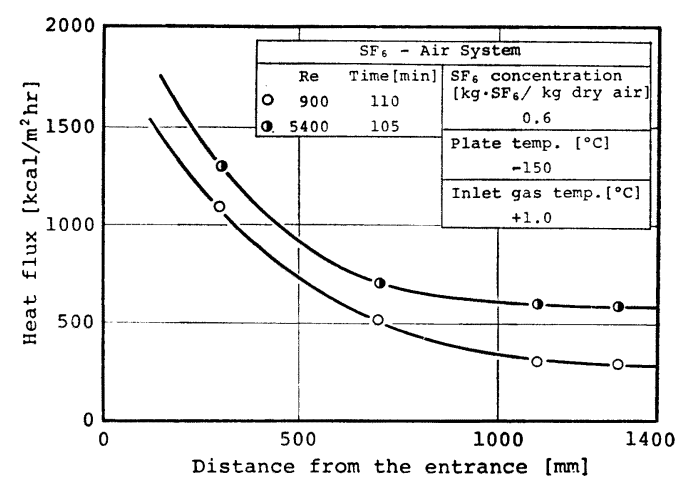

Fig. 3 Distribution of heat flux along longitudinal position

Fig. 1 Schematic representation of experimental apparatus

Fig. 2 Details of the test section
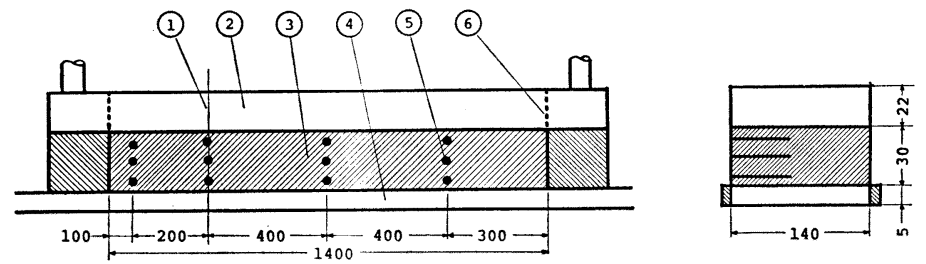

(1) Measuring position

(3) Stainless steel plate

(2) $\mathrm{SF}_{6}$ or $\mathrm{CO}_{2}$ gas - air duct (4) coolant duct

(5) Drilled hole

(6) Perforated plate

断熱に留意した。

\section{$1 \cdot 2$ 測定方法}

伝熱面上に $\mathrm{SF}_{\mathrm{\theta}}$ あるいは $\mathrm{CO}_{2}$ が霜状に析出し析出層 が形成される過程は時間的にきわめて遅く準定常状熊と みなしらる.そこで本実験における析出層・気流間の局 所熱伝達係数 $h$ の測定にあたっては前報 ${ }^{8}$ と同様比較法 の原理を応用した。

気流から析出層へ移動する熱量 $q$ は気流の顕熱移動 量 $q_{c}$ と気流中の $\mathrm{SF}_{\mathrm{B}}$ もしくは $\mathrm{CO}_{2}$ が析出する際に 発生する潜熱移動量 $q_{m}$ の和と考えると, $h$ は Eq. (1) で定義される.

$$
\begin{aligned}
q & =q_{c}+q_{m} \\
& =h\left(t_{a}-t_{f}\right)+w L_{H}
\end{aligned}
$$

なお放射による移動量は推算によると全熱移動量のおよ そ5\% 程度であるのでその寄与は無視した。ここで系全 体が断熱されているとすると $q$ は伝熱板を通り冷媒(液 体窒素)に吸収されるので Eq. (2) が成立する.

$$
q=\frac{\lambda_{s}}{l_{s}}\left(t_{s}-t_{b}\right)
$$

したがって気流温度 $t_{a}$, 析出層表面温度 $t_{f}$, 伝熱板両 面温度 $t_{s}, t_{b}$ および物質移動速度 $w$ などの諸量を測定 することにより Eqs. (1) および (2) より $h$ を求める ことができる.
1) 測定地点 測定部流れ方向各地点での熱流束 $q$ の測定例を Fig. 3 に示した. 熱流束の值は上流では大 きく下流にいくにしたがい次第に減少し, 入口から 1,000 $\mathrm{mm}$ 付近よりその変化は非常に緩慢となり,一見ほぼ一 定値を示す程度に減少していく。このように本実験の $R e$ 数範囲 $(900 \sim 5,400)$ では入口から $1,000 \mathrm{~mm}$ 付近より 下流では気流も充分発達しほぼ定常状態になっているも のと考えられる.な堿線風速計を用いて入口より 600 $\mathrm{mm}$ の地点においてダクト横方向の速度分布を測定し た結果, 充分発達した流れとみなせる放物線分布になっ ていることを確認している. したがって本実験では $h$ などの局所の諸量の測定は入口よりの $1,100 \mathrm{~mm}$ 地点で 行った.

2) 析出層表面温度および析出層厚さ $h$ の決定に 際しては析出層表面温度 $t_{f}$ の測定がその精度を左右す る重要な因子である。しかし析出層表面は粗く凹凸があ り, 㛜密な意味での層表面位置および温度を決定するこ とは困難であるが，ここでは $t_{f}$ 怙よび $l_{f}$ (前報7) と同 様, きわめて細い熱電対により気流中抢よび境界層内垂 直方向の各点の温度および温度変動を測定し, その変動 の上限怙よび下限を外插して求めるいわゆる境界層法に より求めた。

3) 熱流束 局所熱流束 $q$ は伝熱板厚さ方向の温 

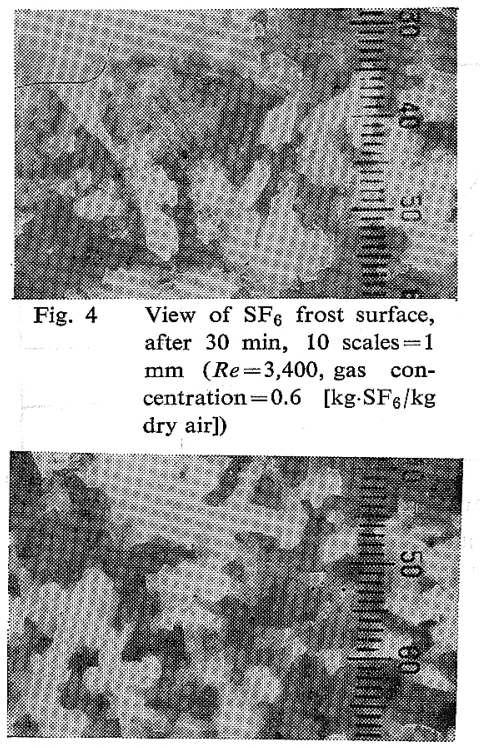

Fig. 5 View of $\mathrm{CO}_{2}$ frost surface, after $30 \mathrm{~min}, 10$ scales $=1$ $\mathrm{mm}$ ( $R e=3,400$, gas concentration $=0.18\left[\mathrm{~kg} \cdot \mathrm{CO}_{2} / \mathrm{kg}\right.$ dry air])

度勾配を測定することにより Eq. (2)より算出した。 こ こでステンレスステール板の熱伝導度 $\lambda_{s}$ はあらかじめ 銅との比較により $-100 \sim-150^{\circ} \mathrm{C}$ の温度域で測定した 值 $\left(\lambda_{s}=10.4 \sim 9.31 \mathrm{kcal} / \mathrm{mhr} \cdot{ }^{\circ} \mathrm{C}\right)$ を用いた.

4) 物質移動速度 物質移動速度 $w$ は各時間ごを に伝熱面上に析出した局所の析出物をかをり科量し, その重量の経時变化より求めた。 な打析出物のサンプリ ング中拉よび秤量中の昇華による減量や空気中の水蒸気 の凝固による堌量などの重量変化は少なく無視できるこ とを前もって確認している。

5) 熱収支 各害験ごとに装置全体での熱収支を取 ることにより測定精度を検討した。熱収支は Eq. (3)の ように出入口での気流温度, 気流流量より求まる顕熱移 動量 $Q_{c}$ と Eq. (4) で示される析出した析出物の重量よ り求京る潜熱移動量 $Q_{m}$ の和 $Q$ と, 伝熱板を通る熱 量 $\sum q$ を比較した。

$$
\begin{aligned}
& Q_{c}=C_{p \rho} V\left(t_{a i}-t_{a 0}\right) \\
& Q_{m}=M_{f} L_{H}
\end{aligned}
$$

その結果，両者の違いは最大で $20 \%$ であり，比較的よ く一致していることを確認した. な拈出口での気流温度 $t_{a_{0}}$ は出口に多孔板を設けることに上り気流を攪汼し測 定した。 なた霜層の堆積による気流流路面積の減少は 120 分を経過した段階でもダクト厚さ $22 \mathrm{~mm}$ に比して 析出層厚さはらすく 2 3 $\mathrm{mm}$ 程度であるため気流速度 の変化は無視した.

\section{$1 \cdot 3$ 実験条件および諸物性}

前述の上うに本実験では混合ガス中に含まれる水分に より霜が析出し $\mathrm{SF}_{6}$ や $\mathrm{CO}_{2}$ の析出層に影響を及ぼす
Table 1 Physical property

\begin{tabular}{cccc}
$\begin{array}{c}\text { ublimation } \\
\text { emperature } \\
{\left[{ }^{\circ} \mathrm{C}\right]}\end{array}$ & $\begin{array}{c}\text { Density of } \\
\text { solid } \\
{\left[\mathrm{kg} / \mathrm{m}^{3}\right]}\end{array}$ & $\begin{array}{c}\text { Thermal conduc- } \\
\text { tivity of solid } \\
{\left[\mathrm{kcal} / \mathrm{m} \cdot \mathrm{hr} \cdot{ }^{\circ} \mathrm{C}\right]}\end{array}$ & $\begin{array}{c}\text { Latent heat } \\
{[\mathrm{kcal} / \mathrm{kg}]}\end{array}$ \\
\hline-63.5 & 2,683 & $\begin{array}{c}0.34^{*} \\
\text { (by author) } \\
0.46\end{array}$ & 38.19 \\
-78.5 & 1,565 & $\begin{array}{c}0.45^{*} \\
\text { (by author) } \\
1.90\end{array}$ & 137.0 \\
$\begin{array}{c}0 \\
0\end{array}$ & 915 & & 676.0 \\
\hline melting point) & & &
\end{tabular}

ことが考光られる.このため水分の影響について検討す るため, 本実験で使用した脱湿装置で得られる乾燥空気 (絶対湿度 $0.0001 \mathrm{kgH}_{2} \mathrm{O} / \mathrm{kg}$ dry air 以下)のみを所定の $-150^{\circ} \mathrm{C}$ に冷却した測定部に流しブランクの実験を行っ た，その結果，水の霜はこの一連の穾験での最長時間で ある 120 分を経過しても，入口より $200 \mathrm{~mm}$ 付近まで にごくわずか析出するのみでそれより下流にはまったく 析出しなかったまな実験中に供給される全乾燥空気中 に含恋れている水分法 $R e$ 数 5,400 の場合でも $2.5 \mathrm{~g}$ 程 度 (120 分間中に)であり, 仮に $100 \%$ 析出したとしても $\mathrm{SF}_{6}$ または $\mathrm{CO}_{2}$ の全析出量 $1,500 \sim 900 \mathrm{~g}$ に比べきわ めて少なく，熱収支，サンプリングなどの祭にも汪とん ぞ影響を与えないものと思和机。しか子局所の諸量の 測定は入口より $1,100 \mathrm{~mm}$ の地点で行っているのでこの 乾燥空気を用いても水の霜の影響はほとえどないと考兄 られる。

Table 1 飞 $\mathrm{SF}_{8}, \mathrm{CO}_{2}$ の諸物性值の交献值を示した. 参考のため $\mathrm{H}_{2} \mathrm{O}$ の場合も示した。な和 $\mathrm{SF}_{\mathrm{\theta}}$ 抒よび $\mathrm{CO}_{2}$ の固体の熱伝導度の值（*印）は著者らが比較法により 求めたものである。

\section{2. 析出層の性状}

\section{1 析出層の観察}

成長過程に㔚ける $\mathrm{SF}_{6}$ ・空気系就よび $\mathrm{CO}_{2}$ ・空気系 の析出層を上方から撮影した写真をそれぞれ Figs. 4 和 よび 5 に示した。写真からわかるよらに両系とも析出層 表面は平坦ではなく凹凸をるっており，混合がス系の種 類に上りその性状虫かなり異なっているのが方かる。一 般化 $\mathrm{CO}_{2}$ 系の方が結晶が比較的はっきりして和り結晶 質的であるのに比へ， $\mathrm{SF}_{6}$ 系は結晶があまりはっきりせ ず非晶質的な感じを与える.

\section{$2 \cdot 2$ 物質移動量}

$\mathrm{SF}_{6}$ 系拉上び $\mathrm{CO}_{2}$ 系に㧊ける局所の物質移動量, す なわら析出量の経時変化をそれぞれ Figs. 6 怙よび 7

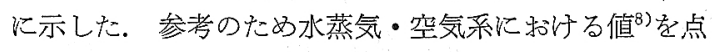
線で示した. 両系とも物質移動量は時間とともにほぼ直 線的な增加を示し，気流速度が大なる核ど物質移動係数 が大きくなるため物質移動量は多くなっている，香た漕 度が低い場合 $\left(0.3 \mathrm{~kg} \mathrm{SF}_{6} / \mathrm{kg}\right.$ dry air, $\left.R e=5,400 ; ه\right)$ は 濃度推進力が小さくなるため物質移動量は少なくなって 
Fig. 6 Variation of local mass deposited wiht time ( $\mathrm{SF}_{6}$-Air system)

Fig. 7 Variation of local mass deposited with time $\left(\mathrm{CO}_{2}\right.$-Air system)
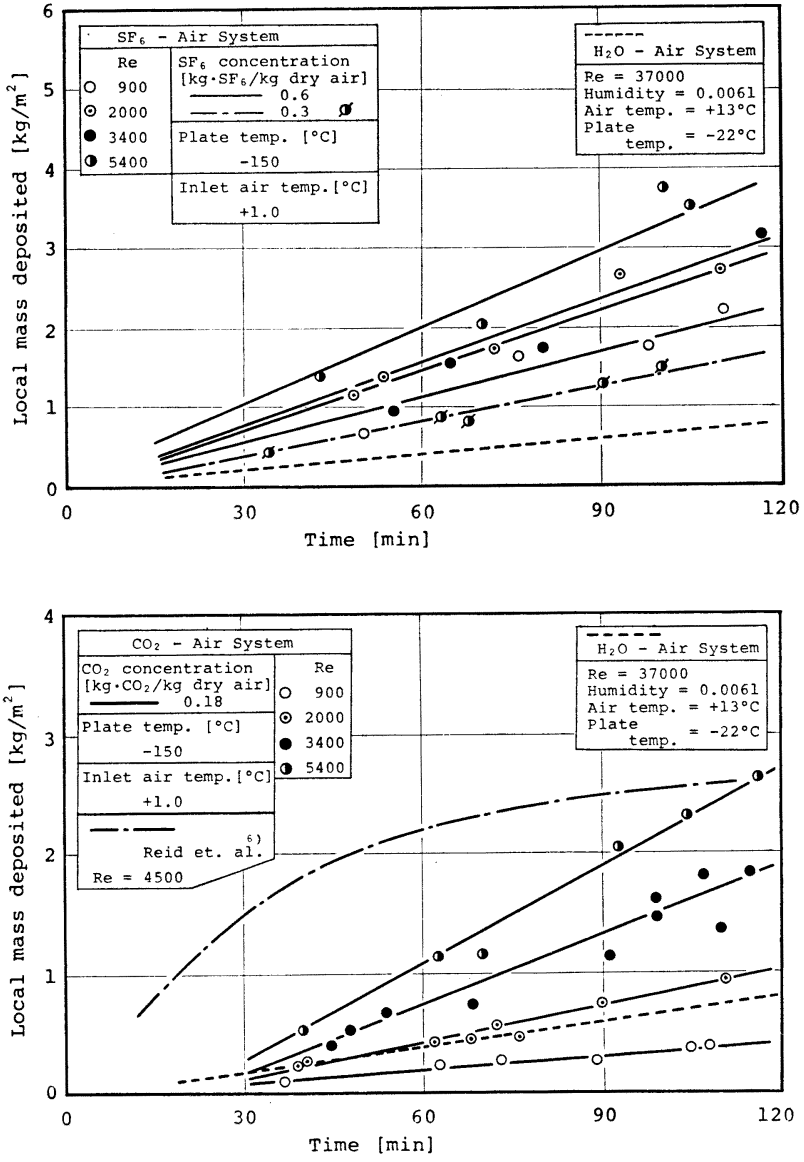

系の析出層に比べ層の空吵率がかなり大きいため霜層内 部での水蒸気の拡散により霜層の緻密化が進みやすいと 考えられること,さらには拡散係数が水蒸気, $\mathrm{SF}_{6}, \mathrm{CO}_{2}$ 系でそれぞれ $0.079,0.022,0.033 \mathrm{~m}^{2} / \mathrm{hr}$ であり, 水蒸気 系の場合他の系に比べ 2 3 倍大きく, 層内部での拡散 による物質移動の寄与が大きいことが考えられる. また $\mathrm{CO}_{2}$ 系の方が $\mathrm{SF}_{6}$ 系よりも拡散係数が若干大きいとい うことが, $\mathrm{SF}_{6}$ 系の場合は増加率が減少傾向, $\mathrm{CO}_{2}$ 系の 場合はほ汇一定の傾向といった違いを生じているとも考 えられる、しかし層内部は複雑に入りくんでおり単なる 拡散係数ではなく有效拡散係数を考える必要があると思 われる. 著者らはすでに水蒸気・空気系の霜層の場合に ついて空陌部での物質移動などについて検討を行ってい るが99, 今後は他の系の場合についても検討を行ってい く必要があるものと思われる.

な招 Fig. 9 中に示した点線は Reid ら ${ }^{6)}$ が $\mathrm{CO}_{2}-\mathrm{N}_{2}$ 系において測定したものであるが絶対值およびその傾向 が本実験結果と異なっている. これは彼らの実験では混 合ガス中の水分の除去が不十分であったため，および助 走区間を考慮していないため，水の霜も同時に生成しそ の影響が出たことによるものと思われる. 

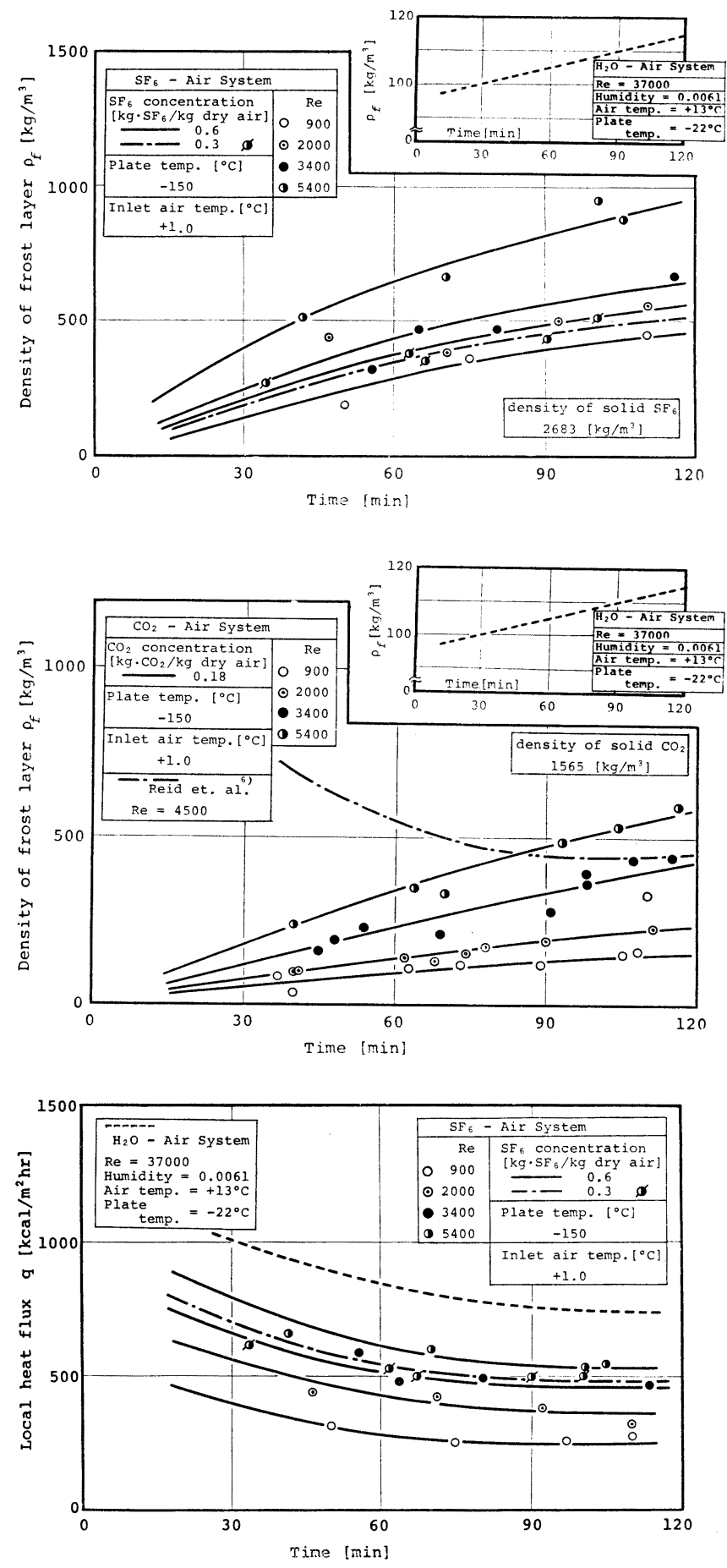

Fig. 8 Variation of frost layer density with time $\left(\mathrm{SF}_{6}-\mathrm{Air}\right.$ system)
Fig. 9 Variation of frost layer density with time $\left(\mathrm{CO}_{2}\right.$-Air system)
Fig. 10 Variation of local heat flux with time ( $\mathrm{SF}_{6}$-Air system)

\section{3. 熱伝達係数}

\section{3・1 熱移動速度}

$\mathrm{SF}_{6}$ 系拉よび $\mathrm{CO}_{2}$ 系における局所熱流束の経時変化 をそれぞれ Figs. 10 および 11 に示した. 両系とも水 蒸気・空気系の場合と同様，時間の経過とともに熱流束
は減少し，各条件下でそれぞれ一定值に近づく傾向が見 られる。これは析出層が厚くなり，熱抵抗が増すためと 思われる.また $R e$ 数が大きいほど局所熱流束の值は大 きくなって抽り，濃度が低い場合は潜熱移動量が減少す るため $q$ の值は若干小さくなっている.

\section{$3 \cdot 2$ 熱伝達係数の経時変化}


Fig. 11 Variation of local heat flux with time ( $\mathrm{CO}_{2}$-Airsystem)

Fig. 12

Variation of local heat transfer coefficient with time ( $\mathrm{SF}_{6}$-Air system)

Fig 13. Variation of local heat transfer coefficient with time $\left(\mathrm{CO}_{2}\right.$-Air system)
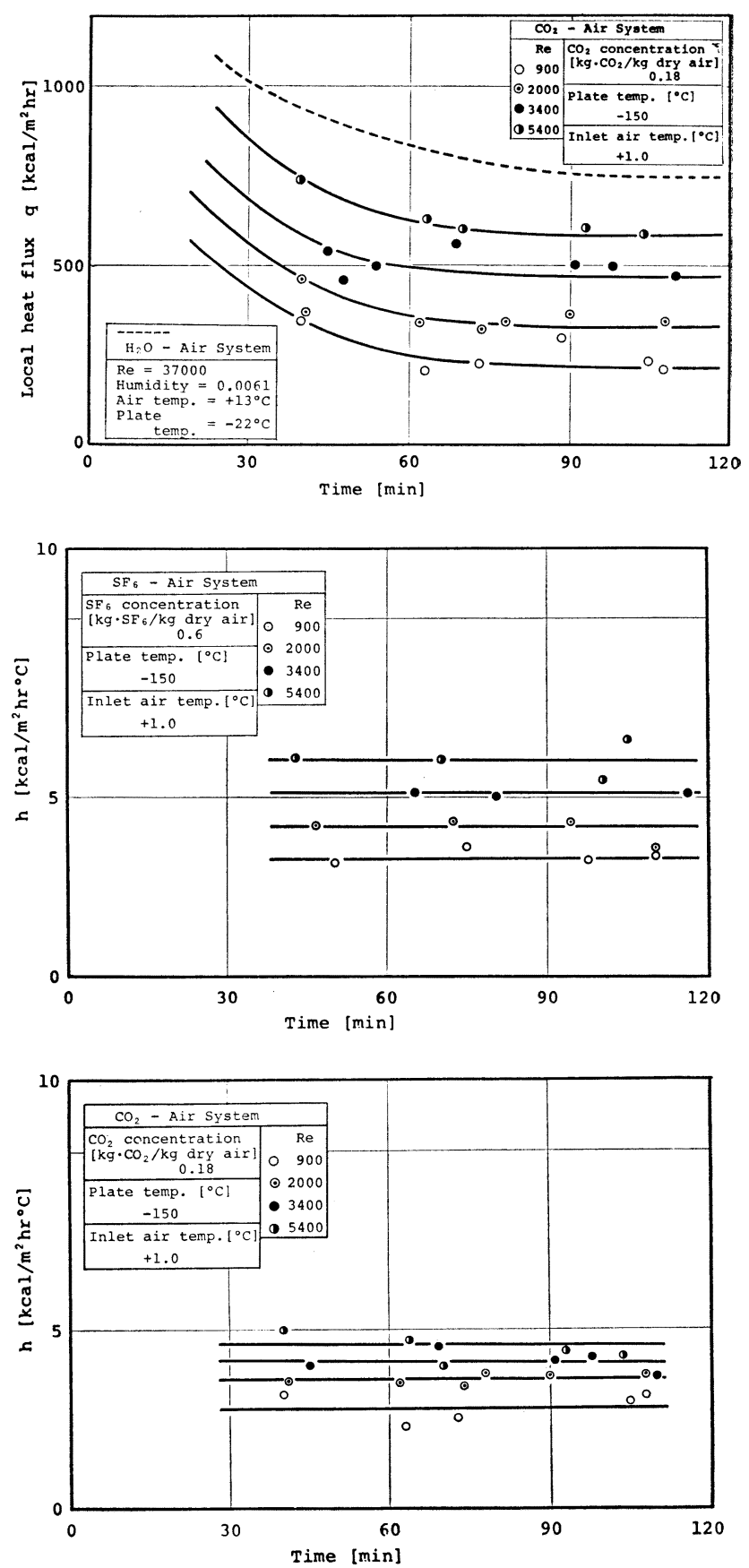

$\mathrm{SF}_{6}$ 系および $\mathrm{CO}_{2}$ 系における析出層・気流間の局所 熱伝達係数の経時変化をそれぞれ Figs. 12 および 13 に示した. 熱伝達係数は $R e$ 数が大きくなるほど大きい 值を示しており，実験開始後約 40 分を経過すると，そ の值は変化が少なくほぼ一定の值を示している．また熱 伝達係数 $h$ の值は両系で注ぼ同程度の值を示している.

しかし 40 分以前の析出層の性状変化のはげしい初期 段階では, $h$ の挙動がぞのようになるのかは興味ある問
題である．今回は準定常状態を仮定し比較法による測定 を行っている関係上変化のはげしい初期段階は除いてい る.

\section{$3 \cdot 3 \mathrm{Nu}$ 数と $\mathrm{Re}$ 数の関係}

Fig. 14 にu 数と $R \mathrm{e}$ 数の関係を示した. 無次元 数中の代表長さとしては伝熱相当径を用いた. 図中に示 したの打よびO印はそれぞれ $\mathrm{SF}_{8}$ ・空気系および $\mathrm{CO}_{2}$ ・ 空気系の場合を示しており，実線は結霜を伴わない熱移 


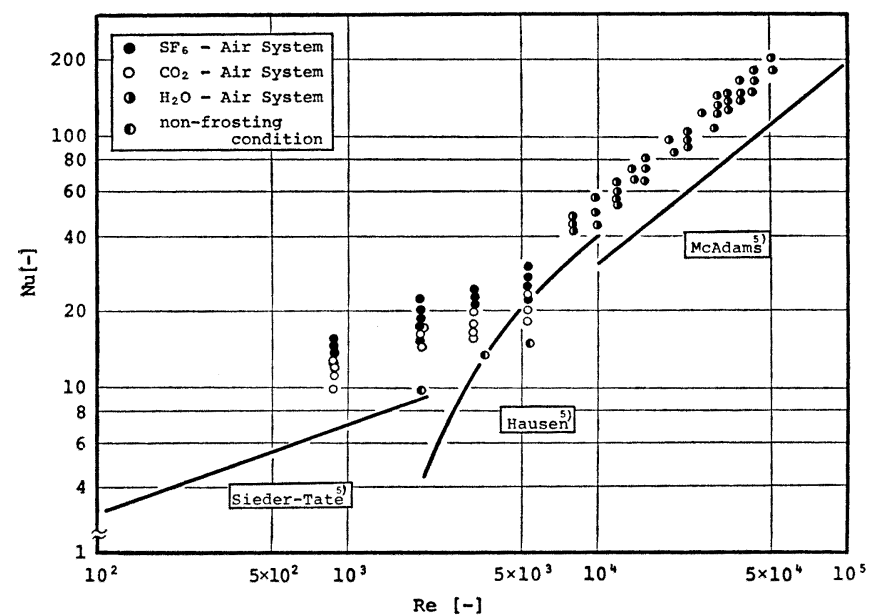

Fig. 14 Relationship between Nusselt number and Reynolds number

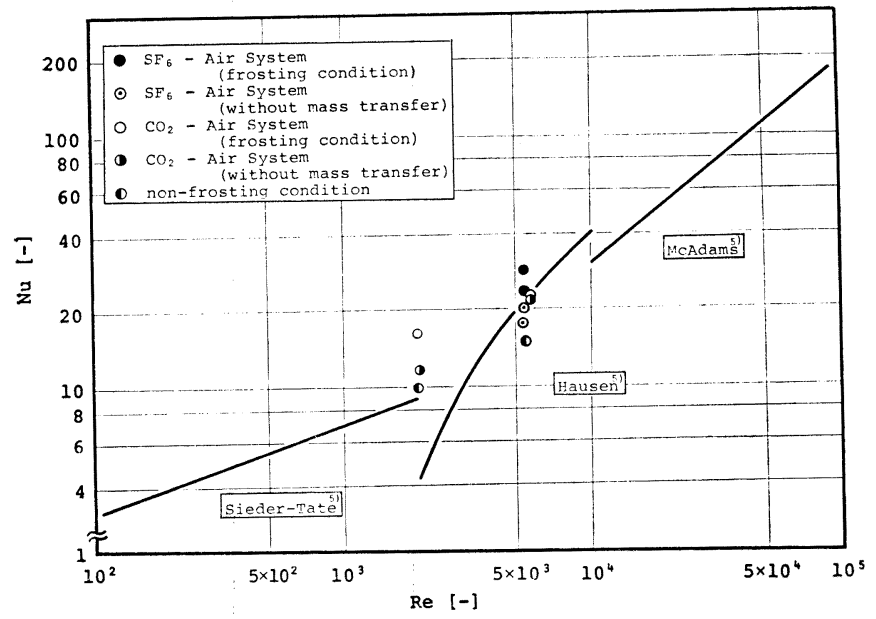

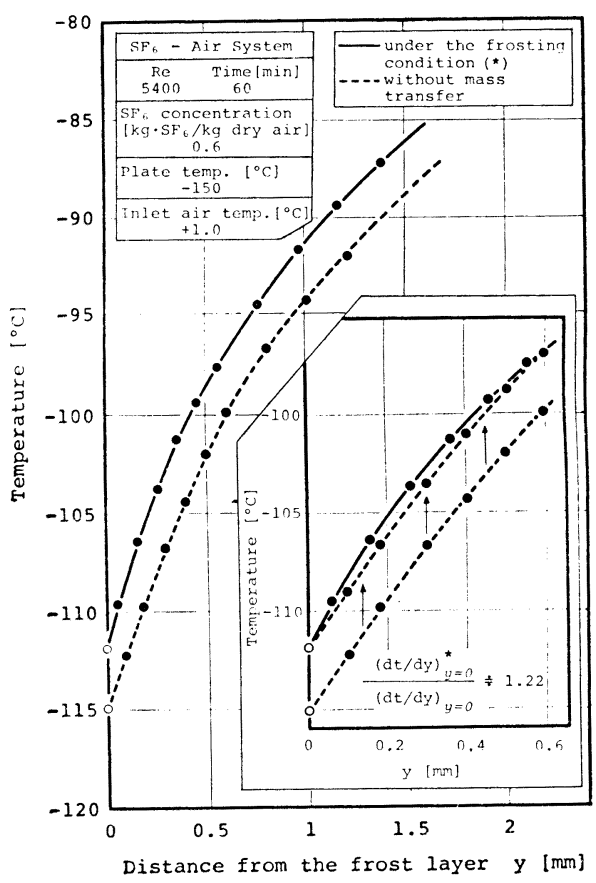

Fig. 15 Temperature distribution in gas stream under frosting condition and without mass transfer

Fig. 16 Relationship between Nusselt number and Reynolds number (effect of mass transfer)
動のみの場合, いわゆる単純伝熱の場合の既往の式 5 で ある、さらにの印は本実験装置を用いて行った結霜を伴 わない熱移動のみ(単純伝熱)の場合の実測值であり, こ れらの值は既往の式と比較的よく一致している.なおこ の実験は乾燥空気を $-150^{\circ} \mathrm{C}$ に泠却した伝熱面に流し て行ったもので実験条件は結霜時のものと同一である.

結霜時における本実験の結果, $N u$ 数の值は熱移動の みの場合に比べ 1.5 2 倍程度大きな值を示している.

これ活流下にお汀る著者らの水蒸気・空気系の場合で のおよそ 1.5 倍大きくなるといら結果 ${ }^{8)}$ とほ涪同様であ る.

結霜過程汸活る熱伝達俰数がこのように大きくなる 理由として, 定性的には(1)析出層表面の凹凸による伝熱 面積の増加, (2)凹凸迈境界層の乱れ, (3)物質移動の 影響などが考えられるがこれらについては次項で検討す る.

\section{3 ・4 熱伝達俰数に及ぼす物啠移動の影響}

物質移動が存在する場合の熱伝垟保数への影留汇つい てはいろいろな考方方が提示されて扔り伝熱関倸の分野 では目下興味ある対象とされている.

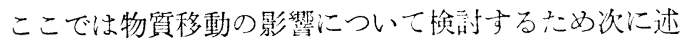
べるような実験を行った，析出原を析出させる結霜時の 実験が終了後, 層隹面温度に活涪相当する分圧を示す濃 度の混合ガスを実験終了時と同じ析出層走面汇流し物質 移動のほとんど起こらない状態で实験を行い熱伝澾係数 を求めた. その結果を $N u$ 数と $R e$ 数の関保で Fig. 15 中に示した. $\mathrm{SF}_{6}$ 系, $\mathrm{CO}_{2}$ 系之も $\mathrm{Nu}$ 数は物質移動の ある場合（・，○印）の方が物質移動のない場合 $(\odot$, ○印）に比べ大きくなっている．ま熱移動のみの場合 の值（の印）之物質移動のない場合の值 $(\odot ，)$ 印之 の間が析出層の表面状態による影響, すなわち析出層表 面の凹凸による伝熱面積の增加や境界層の乱れといった 
影響を表していると考えられる。しかしこのような析出 層表面の凹凸の影響については，その粗さを定量的にと らえることがはなはだ困難であり，かかる場合の熱伝達 係数を表面状態を加味し定量化することは現在の段階で は困難である.

物質移動がある場合にこのように熱伝達俰数が大きく なる理由としては，定性的には境界層内で $\mathrm{SF}_{6}$ や $\mathrm{CO}_{2}$ が凝固する際, 潜熱を放出し周囲の気体を温め物質移動 がない場合に比へ温度勾配がきつくなり温度境界層が薄 くなるため熱伝達係数が大きくなると考えられる．Fig. 16 に析出層表面近傍での気流の温度分布を物質移動の ある場合とない場合について実測し示した，実線は物質 移動のある場合，また点線は物質移動のない場合であ る. 挿入図に示すように両温度分布を層表面位置で重ね 合わせて比較すると，四から明らかであるように物質移 動のある場合の方がない場合よりも層表面での温度勾配 は急になっており前述の考兄方を裏付けているものと考 えられる.な拉この際両系の温度推進力は注注等しい。

以上のように $\mathrm{SF}_{6}$ ・空気系扰よび $\mathrm{CO}_{2}$ ・空気系に打 いても前報 ${ }^{8}$ の水蒸気・空気系の場合之同様, 物質移動 がある場合潜熱発生なぞにより熱伝達係数が単純伝熱の 場合に比べ大きくなることがわかった。

\section{結言}

結霜を伴う混合ガスの分離過程での伝熱機構を解明す る目的で, $\mathrm{SF}_{6}$ ・空気系拉よび $\mathrm{CO}_{2}$ ・空気系の混合ガス を用い，強制対流下の結霜現象について実験を行った。 析出層の性状, 物質移動量, 析出層密度, 析出層・気流間 の局所熱伝達係数などを求め検討を行った，その結果，

（1）物質移動量は両系とも2 時間程度までは時間の 経過とともに注ぼ一定の割合で増加し，また $R e$ 数が大 きい注ど移動量は多い。

（2）析出層の密度は両系とも時間とともに增加し， その增加率は一定かやや城少する傾向を示した。 また $R e$ 数が大きいほど密度は大きい。

（3）熱伝達係数 $h$ は両系とも時間による変化は少な く各 $R e$ 数でほぼ一定の値を示した。 また $h$ の値は $\mathrm{SF}_{6}$ 系, $\mathrm{CO}_{2}$ 系とも注ぼ同程度の值を示した。ささらに熱伝達 釈数は物質移動および層表面粗さの影響を受け単純伝熱 の場合より 1.5 2 倍程度大きな値を示した。物質移動 の $h$ に及汇す影響をみるため，析出層存在下で物質移 動の起きない状態での実験を行ったところ $h$ はその影 響でかなり大きくなることがわかった。
[付 記] 実験試料の一部については(株)日立製作 所日立研究所よりご便宜をいただいた。 また本研究費の 一部は旭硝子工業技術奖励会のご援助によったことを記 して感謝の意を表する，また実験装置製作にあたっては 東北大学工学部化学系工場の香味賢一, 佐藤一幸両氏の 助力を得た.

\section{Nomenclature}

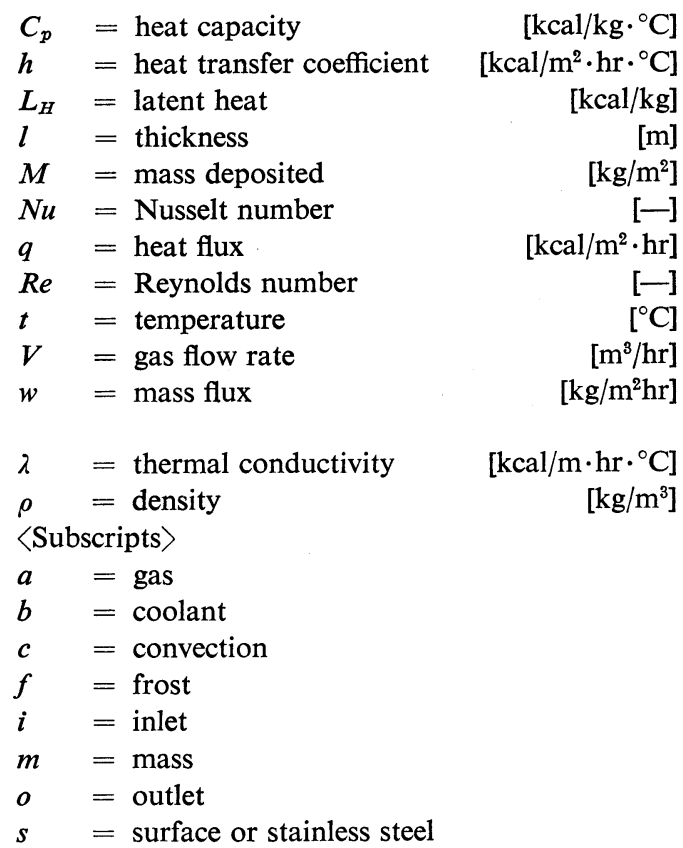

\section{Literature cited}

1) "Gemelins Handbuch der anorganischen Chennie 8 Auf.", B-3, 1710 (1963)

2) ibid. C-1, 361 (1970)

3) Hasatani, M., Y. Aoyama and S. Sugiyama: J. Chem. Eng. Japan, 8, 20 (1975)

4) “Kagaku Benran Kisohen” 2nd. ed. Maruzen (1975)

5) McAdams, W. H.: "Heat Transmisson 3rd. Ed" McGrawHill (1954)

6) Ogumbameru, A. N., P. L. T. Brian and R. C. Reid: Ind. Eng. Chem. Fundam. 12, 385 (1973)

7) Yamakawa, N., N. Takahashi and S. Ohtani: Kagaku Kögaku, 33, 699 (1969)

8) Yamakawa, N., N. Takahashi and S. Ohtani: Kagaku Kōgaku, 35, 328 (1971)

9) Yamakawa, N. and S. Ohtani: Kagaku Kōgaku, 36, 197 (1972)

10) Yamakawa, N., F. Kawamura and S. Ohtani: Kagaku Kógaku, 37, 373 (1973)

11) Yamakawa, N., H. Aoki, S. Ohtani and S. Maeda: Preprints of the 11 th Heat Transfer Symposium of Japan, 317 (1974)

(1976 年 8 月 2 日受理；第 12 回日本伝熱シンポジウム (福岡, 1975 年 5 月)にて発表) 


\title{
Heat Transfer by Forced Convection under Frosting Condition
}

- The case of $\mathrm{SF}_{\theta^{-}}$air and $\mathrm{CO}_{2^{-}}$air systems-

\author{
Fumio Kawamura, Tokio Shimada, Norio Yamakawa \\ and Shigemori Ohtani \\ Dept. of Chem. Eng., Tohoku Univ., Sendai, 980
}

The local heat transfer coefficients ' $h$ ' were measured under freezing condition by passing two gas mixtured (air-sulferhexafluoride $\left(\mathrm{SF}_{6}\right)$ and air-carbondioxide $\left(\mathrm{CO}_{2}\right)$ ) between paralell flat plates. Furthermore, in order to investigate the effect of mass transfer on ' $h$ ', the local heat transfer coefficients without any mass transfer afresh on the deposited layer were measured and compared with that under frosting condition.

The experimental data showed that the difference of the systems had not much effect on the values of the heat transfer coefficient under frosting conditions. However, these values were $150 \sim 200 \%$ larger than those estimated by the Sieder-Tate and Hausen equations. The reasons of this were considered to be due to the interference of heat and mass transfer and the frost surface roughness, which caused an increase of the heat transfer area and disturbance of the boundary layer. 